\title{
Lazaroa
}

ISSN-e 1988-3307

\section{Contribution to the phytotherapy against scorpion sting envenomation in the Naama region (Algeria)}

\author{
Hafidha Boucherit ${ }^{1,3}$; Khéloufi Benabdeli ${ }^{2} \&$ Abdelkrim Benaradj $^{3}$
}

Received 9 November 2016 / Accepted 27 April 2017

\begin{abstract}
Scorpion envenomation represents one of the most important public health problems in Algeria and particularly in the High Plateaus and the South regions. Every year, several thousand people are stung by scorpion and an average of one hundred die. In the region of Naama, nearly 1500 people are bitten annually; mainly at the beginning and at the end of the summer period; and, on the average, three die from the consequences of these bites. The study is prospective and was carried out over a period of three months between December 2015 and February 2016. It is based on a survey supported by fifty questionnaires for the population and herbalists in the Naama region.

Results showed that the most widely used plant species was Hammada scoparia, commonly known as "Remt", with a percentage of $74 \%$, much higher than the rest of used plants in the area and it should be studied in detail. One teaspoon of Hammada scoparia powder combined with a tablespoon of pure butter (from ovine milk for instance) and cooked at low heat is the most used remedy. $50 \%$ of the surveyed people answers they are convinced this treatment is the most efficient to have all active compounds of the species.
\end{abstract}

Keywords: Phytotherapy; Scorpion Envenomation; Hammada scoparia; Naâma; Algeria.

\section{[es] Contribución a la fitoterapia para el tratamiento de picadura por escorpión en la provincia de Naama (Argelia)}

Resumen. El envenenamiento por picadura de escorpión es uno de los problemas de salud pública más importante en Argelia, y en particular en las regiones montañosas o al sur del país. Cada año miles de personas son picadas por un escorpión, de las que unas cien fallecen. En la provincia de Naama 1485 personas sufren picaduras de escorpión anualmente, sobre todo al principio y al final del verano, falleciendo un promedio de tres personas al año.

El estudio realizado se llevó a cabo durante un período de tres meses entre diciembre de 2015 y de febrero de 2016; y se basa en cincuenta encuestas realizadas a la población y también a los herbolarios de la región de Naama. Los resultados mostraron que las especies más utilizadas son Hammada scoparia, con un 74\%, resultando la más utilizada de todas y por ello debería ser estudiada más detalladamente. Una cucharada de polvo Hammada scoparia asociado con una cucharada de mantequilla pura (de oveja, por ejemplo) y cocinado a fuego lento es la forma de preparación que utiliza el $50 \%$ de los encuestados, que piensan que es la forma más eficiente de recoger los principios activos de la planta.

Palabras clave: Fitoterapia, picadura de escorpión, Hammada scoparia, Naâma, Argelia.

\section{Introduction}

For centuries, man has always treated himself by plants, empirically, guided by tradition or customs. Most of the great doctors of the past have been herbalists (Goeb, 1999). Medicinal plants have been used since antiquity to allevi- ate and cure human diseases and still remain a source of medical care in developing countries in the absence of a modern medical system (Tabuti \& al., 2003). Among these diseases, scorpion stings are a major public health problem in the Naama region, as they are the leading cause of intoxication according to studies.

\footnotetext{
Department of Agronomy, Faculty of Sciences, Nature and Life and Universe, Abou Bekr Belkaid University. Tlemcen, Algeria. E-mail: h.boucherit@yahoo.fr

2 Department of Biology, Laboratory of Geo-Environment and Development Spaces, Faculty of Natural Sciences and Life, University Stambouli Mustapha. Mascara, Algeria.

3 Department of Biology, Institute of Science and Technology, University Center Salhi Ahmed. Naama, Algeria.
} 
Medicinal plants have therapeutic properties due to the presence of hundreds or even thousands of natural bioactive compounds called secondary metabolites. The latter are subsequently accumulated in different organs, and sometimes in specialized cells, of the plant (Boudjouref, 2011). The use of medicinal plants by man in Naama region, as in all the southern part of Algeria, has been practiced for centuries and continues to be so. The study of the therapeutic effect of certain local plant species on envenomation scorpion is the objective of this investigation.

\section{Scorpion envenomation}

\section{Envenomationvectors: Androctonusaustralis L. and Buthus occitanus A.}

Scorpions are old insects that appeared on Earth in the primary era, four hundred million years ago (approx.). The fossils of these first specimens show a very similar morphology to that of the present scorpions (Vachon, 1952). They are terrestrial arthropods that resist all the environment aggressive factors (Soulaymani \& al., 1999). Nearly 1500 species of scorpions are described throughout the world, only a few of which are dangerous to man. Among these two are endemic from Algeria and are responsible of a high morbidity and mortality: Androctonus australis is a large brown scorpion that can reach up to $10 \mathrm{~cm}$, some parts of which are darker (the tongs and the last rings of the tail), its tail is thick. It is the most dangerous species; its venom is powerful and contains 6 toxins. Buthus occitanus is a medium sized scorpion (4 to $7 \mathrm{~cm}$ ), of clear tint, the claws and the legs are brighter and its tail is slender. Its range is wide and its dangerousness is variable.

Scorpions live in groups (Vachon, 1952). They are found in various habitats: under stones, rocks, bark of trees and old buildings. They seek dark corners where they dig burrows (Ismail, 2003; Isbister \& al., 2003). They are nocturnal, of fearful nature, not very aggressive and lucifuge (Goyffon \& El Ayeb, 2002). Active in the spring and summer, they enter into hibernation early in the fall (Sadine, 2005). Androctonus australis, opportunistic species, omnipresent in all biotopes, is the only species that lives close to man.

\section{Scorpion Envenomation in Algeria}

Scorpion envenomation is the result of the sting of a person by a scorpion (Sadine,
2005). Scorpion bites are a major public health problem in many countries (Isbister \& al., 2003, Isbister \& Bawaskar, 2014). Scorpion bites are a major public health problem in many countries, particularly those in North Africa, Saharan Africa, India, the Near and Middle East, Mexico and South America. The world annual number, in 2008, of scorpion stings was estimated at 1.2 million with 3250 deaths $(0.27 \%)$. In Algeria, scorpion envenomation (S.E.) was recognized in the mid1980 as a public health problem. Because of the morbidity and mortality it causes and the financial burden it imposes (Benhabyles, 1990; Laid, 1998). The population at risk of scorpion envenomation has steadily increased, particularly during the last decade (estimated at $71.9 \%$ in 2010 , compared to $29.6 \%$ in 1997 ). 26 wilaya's (Territorial province) (54.5\%) reported 35,497 cases of scorpion in 1997 (N.I.S.P. (National Institute of Public Health), 1997). In 2010, they are 38 wilaya's to have declared 49,574 sting cases (N.I.S.P., 2010). On the national territory, 28 species and 14 genera of scorpions, classified under 3 families: Buthidae, Chactidae (Euscorpiidae) and Scorpionidae were recorded (Dupre, 2011).

\section{Scorpion Envenomation in Naama region}

The wilaya of Naama is inserted between the Tellian Atlas in the North and the Saharan Atlas in the South (Figure 2). It covers a 29825 $\mathrm{km}^{2}$ area where three homogeneous geographical zones emerge:

A steppe zone constituted by a vast plain and occupying $74 \%$ of the territory of the province.

A mountainous area located in the southwestern region reaching $2000 \mathrm{~m}$ asl of altitude and representing the $12 \%$ of the total area.

A pre-Saharan zone covering the $14 \%$ of the total area of the province.

This region has experienced a high number of scorpion stings mainly due to edaphic and climatic conditions. The latter are characterized by 9 hot and dry months. In 2015, 1485 victims of scorpion smears were recorded across all municipalities in the wilaya according to the Direction of Health and Population of Naama (D.H.P. Naama). Figure 1 shows the number of stitches and deaths from 2005 to 2015 per commune (Akin County). 


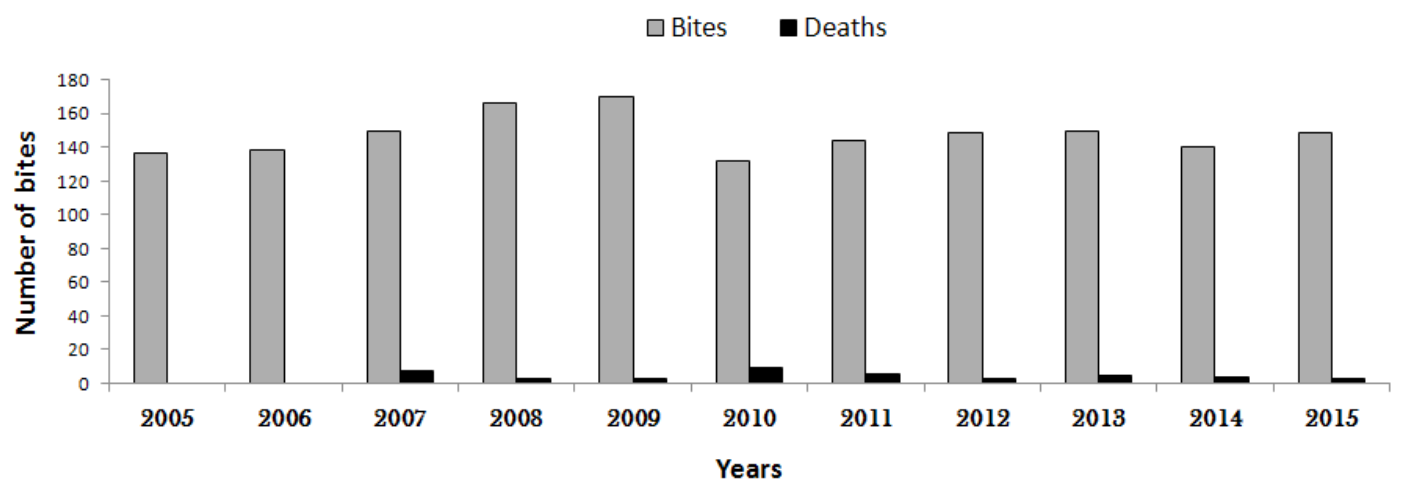

Figure 1. Number of bites and deaths from 2005 to 2015 in the wilaya of Naama (Anon., 2015).

The spatial concentration of scorpion bites for the year 2015 (Figure 2) is mainly found in Ain Sefra, Mecheria and Ain Ben Khelil. It is an important spatial indicator that correlates with environmental conditions (old buildings in particular); scorpions live around the rocky and sandy regions, under stones or in burrows. The scorpion passes the day hidden under rocks or in tunnels it digs in the sand.

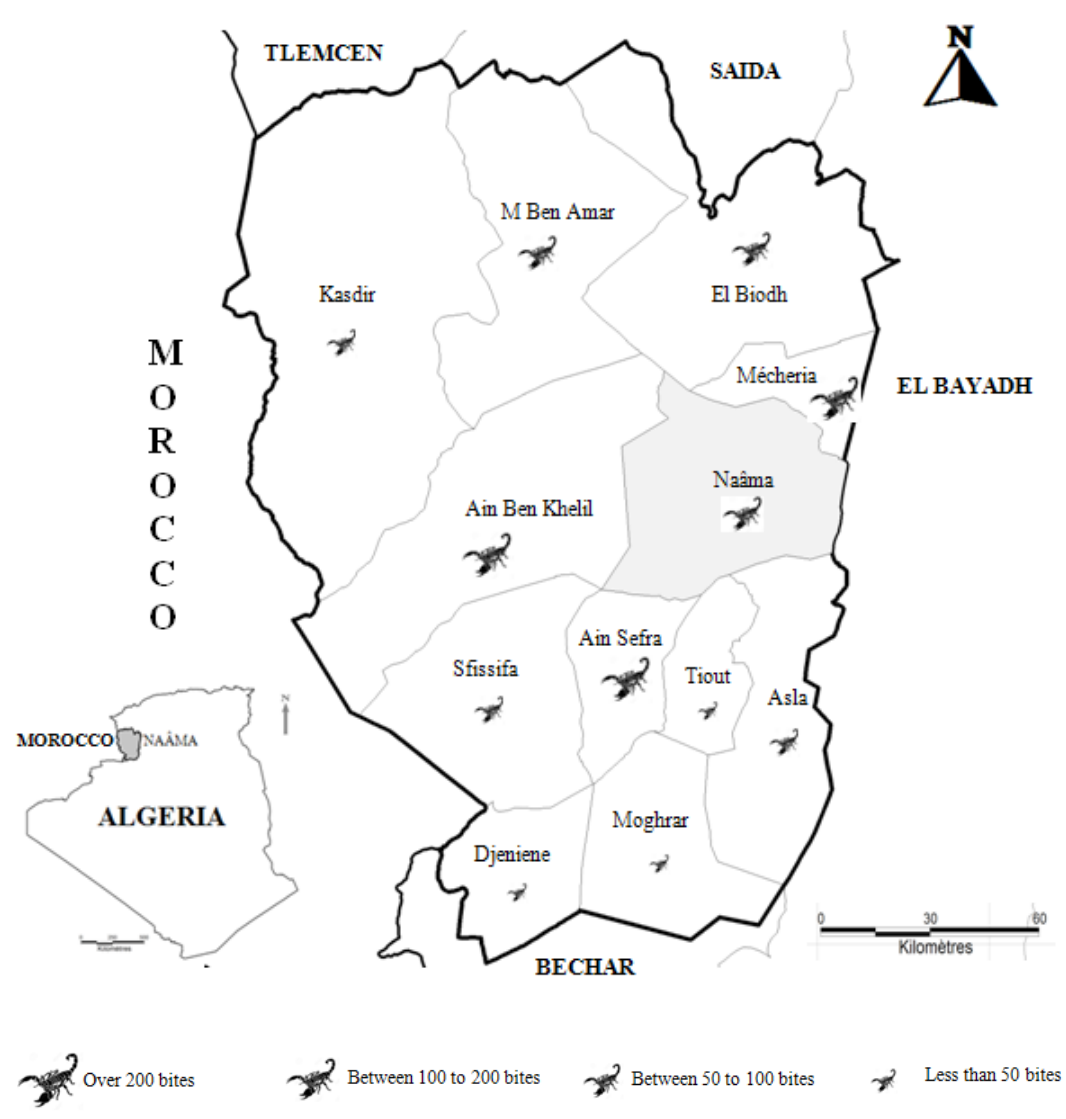

Figure 2. Distribution of scorpion stitches per commune in the wilaya of Naama. 


\section{Materials and methods}

The ethnobotanical study was carried out between December 2015 and February 2016 through a survey at three sites: Mecheria, Ain Sefra, and Naama; using 50 questionnaires.

Interviews were conducted through open -ended questions, to the local population and herbalists, separately and in the vernacular language. Thus, the profile of each respondent includes age, educational level, family situation, and know-how in relation to the treatment, of scorpion stings, by plants.

The studied parameters are on the plants and their parts used as well as the method of preparation. In order to assess informants on the use of plants against scorpion stings, an Informant Consensus Factor (ICF) was calculated according to the following formula:

$$
I C F=\frac{N a}{N t}
$$

(a)

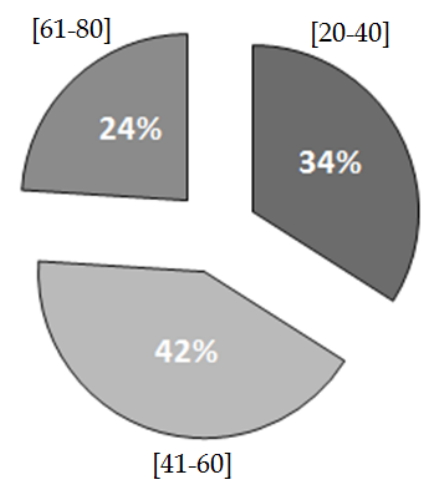

Where $N a$ is the number of informants citing a species and $N t$ the total number of informants (Cotton, 1996).

\section{Results}

The results of our ethnobotanical survey are presented according to the parameters studied (age, level of study, plants used, part of the plant used, and the preparation way).

Age. The informant age range varies from 20 to over 80 years. The higher percentage, $42 \%$, represents people age between 40 and 60 , who have more knowledge and frequently use medicinal plants. However, for the age group of 20 to 40 years, a rate of $34 \%$ is observed, and for people aged between 60 and 80 years, the use of medicinal plants $(24 \%)$ is not of great therapeutic interest.

Level of study. The intellectual levels of plant users are different, it should be noted that $34 \%$ of users of herbal medicine are illiterate. Nevertheless, people with a secondary and/or university level have a significant percentage, of $28 \%$ and $20 \%$ respectively, of medicinal plants use. For those at primary level, medicinal plants are only used by $10 \%$ (Figure 4 ).

Figure 3. Distribution of medicinal plant users by age (a) and level of study (b).

The plants used. The six main local plant species that we have found and which can act against scorpion envenomations are: Hammada scoparia with a percentage of $74 \%$; Artemisia herba-alba with 8\%; Cotula cinerea and Citrullus colocynthis at $6 \%$, Artemisia arborescens with $4 \%$ and Nicotiana tabacum with $2 \%$; belonging to four botanical families (Table 1). 
Table 1. Botanical characteristics and percentage of use (\%) of anti-venomous plant species.

\begin{tabular}{|l|l|l|l|l|c|}
\hline \multicolumn{1}{|c|}{ Species } & \multicolumn{1}{|c|}{ Family } & $\begin{array}{c}\text { Biological } \\
\text { Type }\end{array}$ & \multicolumn{1}{|c|}{ Common name } & \multicolumn{1}{|c|}{$\begin{array}{c}\text { Vernacular } \\
\text { name }\end{array}$} & \multicolumn{1}{c|}{$(\%)$} \\
\hline Hammada scoparia (Pomel.) Iljin & Amaranthaceae & Chamaephyte & Saligne à balai & Remth & $74 \%$ \\
\hline Artemisia herba alba Asso & Asteraceae & Chamaephyte & Armoise blanche & Chih & $8 \%$ \\
\hline Cotula cinerea Del. & Asteraceae & Therophytes & Armoise cendré & Guertoufa & $6 \%$ \\
\hline Citrullus colocynthis (L.) Schrad. & Cucurbitaceae & Therophyte & Coloquinte & Hedaj & $6 \%$ \\
\hline Artemisia arborescens L. & Asteraceae & Chamaephyte & Armoise arborescente & Chhiba & $4 \%$ \\
\hline Nicotiana tabacum L. & Solanaceae & Therophyte & Tabac & Tabagha & $2 \%$ \\
\hline
\end{tabular}

Informant Consensus Factor (ICF). It varies between $0-1$, the calculation of the consensus values of the species revealed weak indices for all the species except for the case of Hammada scoparia for which this index is greater than 0.5 (Table 2).

Table 2. ICF index values on the studied species.

\begin{tabular}{|l|c|}
\hline \multicolumn{1}{|c|}{ Species } & ICF \\
\hline Hammada scoparia (Pomel) Iljin & 0.74 \\
Artemisia herba alba Asso & 0.08 \\
Cotula cinerea Del. & 0.06 \\
Citrullus colocynthis (L.) Schrad. & 0.06 \\
Artemisia arborescens L. & 0.04 \\
Nicotiana tabacum L. & 0.02 \\
\hline
\end{tabular}

Hammada scoparia (Pomel) is a Saharan-Mediterranean species. It reaches an ICF of 0.74 because it is cited by the majority of the respondents. It is a shrub with very small stalks, which blacken in drying, with short floral ears, brightly colored winged fruits often pink or red. Hammada scoparia develops in, from the Upper Arid to the Lower Saharan bioclimatic ranges, with variants with mild, cool winters; on loamy brown soil; usually on the degraded steppe of white wormwood. It is very common on Regs (Rocky areas in the Saharan regions) with gypsum soils.

Useful Parts. The plant parts used are ranked in order of importance: leafy stems $(60 \%)$ followed by leaves $(22 \%)$, fruits and seeds $(6 \%)$, flowers $(4 \%)$ and the whole plant represented by $2 \%$ (Figure 4 ). 


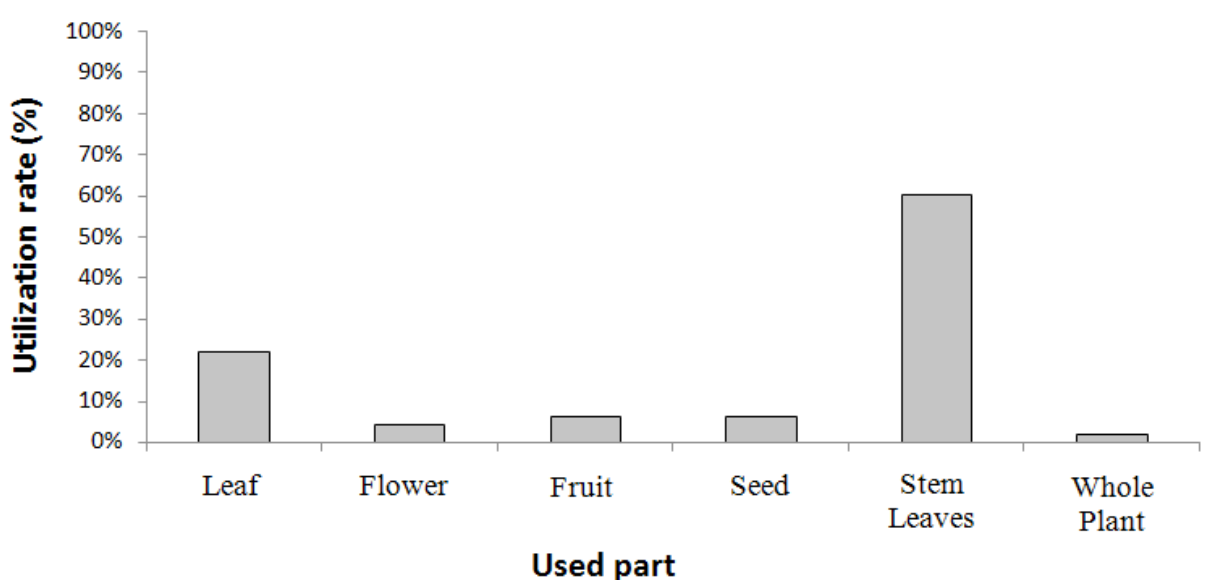

Figure 4. Percentages of plants parts used in the medicinal species analyzed.

Mode of preparation. Hammada scoparia powder is the most used method of preparation associated with butter at a rate of $50 \%$.Oth- er preparations are used: namely the poultice $(26 \%)$, the natural form $(14 \%)$ and the decoction $(10 \%)$ (Figure 5).

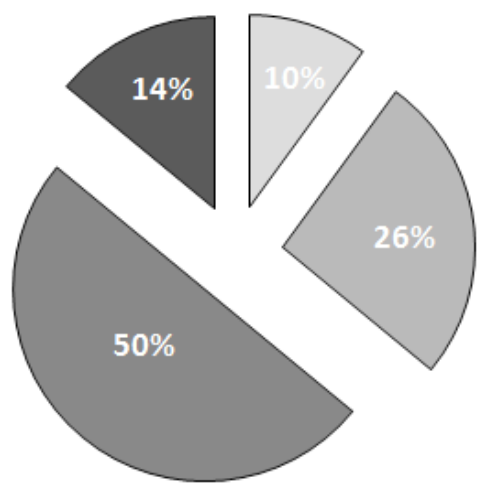

Figure 5. Percentage of preparation modes used by population (see text for explanations).

\section{Discussion}

The use of plants and the products derived from them are increasing as a result of family extension and transmission from generation to generation. The obtained results showed phytotherapy is practiced by the population whatever the age group or the level of study. Surveys of the local population and herbalists showed the therapeutic effect of species such as Hammada scoparia, Artemisia herba-alba, Cotulacinerea, Citrulluscolocynthis, Artemisia arborescens and Nicotiana tabacum, advocated against scorpion stings. There are research focused in some of those plants (Laraba-Djebari $\&$ Kabrine, 2014), although the last five revealed low consensus values (close to 0 ).

Hammada scoparia, with an estimated utilization rate of $74 \%$ and an ICF 0.74 , shows the great interest in the treatment of scorpion envenomation. A teaspoon of Hammada scoparia powder, combined with a tablespoon of pure ovine butter, low heated, is given to the patient immediately after the 
sting. This treatment is the most used; because $50 \%$ of the interviewees are convinced that this mode allows collecting the most active ingredients. In the same context, Larribaud (1952) reports a practice of making a wound around the bite and burning on it a few twigs of Hammada scoparia. Reynier (1954) observed that parts of Hammada scoparia boiled for a long time, until the water turns on a blackish tint, resulted in a lotion with an emetic action. It has also been proved that the aqueous Hammada scoparia extract has an anti-cancer activity and a larvicidal effect which is also traditionally used for scorpion bites (Maiza \& al., 1993; Bellakhdar, 1997; Ben Salah \& al., 2002).
Ethnobotanical surveys carried out in the Naama region allowed to gather practical information on the therapeutic use of anti-scorpion plants species. Among these, Hammada scoparia has the highest ICF value much higher than the rest of studied plants. The aerial part of the plant (stem and leaf) is used in the form of vegetal powder combined with pure sheep butter. In perspective, the traditional pharmacopeia should be embodied in experimental approaches in order to provide scientific evidence on the therapeutic efficacy attributed to these plants in traditional medicine.

\section{References}

Anonymous. 2015. Données sur les Envenimation scorpionique entre 2005 et 2010 dans la wilaya de Naama. Dir. Health Popul. Naama. 5p.

Benhabyles, N. 1990. L'envenimation scorpionique, Rapport mensuel sur la situation épidémiologique $\mathrm{N}^{\circ} 7$ Juillet, INPS Alger.

Bellakhdar, J. 1997. La Pharmacopée marocaine traditionnelle, Médecine arabe ancienne et savoirs populaires. Ibis Press, Paris. 764 p.

Ben Salah, H., Jarraya, R., Martin, M.T., Veitch, N.C., Grayer, R.J., Simmonds, M.S. \& Damak, M. 2002. Flavonol triglycosides from the leaves of Hammada scoparia (Pomel). Chem. Pharm. Bull. 50: $1268-1270$.

Boudjouref, M. 2011. Etude de l'activité anti-oxydante et antimicrobienne d'extraits d'Artemisia campestris L. Option: Biochimie appliquée. Mem. Mag Biochim, Université de Setif. 99p.

Cotton, C.M. 1996. Ethnobotany: Principles and Applications. Wiley \& Sons, Chichester. 424 pp.

Dupré, G. 2011. Annotated Bibliography on African scorpions from ANTI (Systematic, faunistic). 107 p.

Goeb, Ph. 1999. Aromathérapie pratique et familiale. Ed. Cap-d'Agde, MDB. 93pp.

Goyffon, M. \& El Ayeb, M. 2002. Epidémiologie du scorpionisme. Infotox. 15: 3.

Isbister, G.K. \& Bawaskar, H.S. 2014. Scorpion Envenomation. N. Engl. J. Med. 371: 457-463.

Isbister, G.K., Erich, S.V., Corrine, R.B. \& Mark, S.H. 2003. Australian scorpion stings: a prospective study of definite stings. Toxicon. 41: 877-883.

Ismail, M. 2003. Treatment of the scorpion envenoming syndrome: 12-years experience with serotherapy. Int. J. Antimicrob. Agents 21(2): 170-174.

Laid, Y. 1998. L'envenimation scorpionique en Algérie. Rapport mensuel sur la situation épidémiologique n.1. Nat. Inst. Public Health, Alger.

Laraba-Djebari, F. \& Kabrine, M. 2014. Phytotherapy as new approach to treat scorpion envenomation: experimental study. Int. J. Pharm. Sci. Res. 5(5): 1682- 1692.

Larribaud, J. 1952. Tindouf et le Sahara occidental. Arch. Inst. Pasteur 30(3): 244-318.

Maiza, K., Brac de la Perrière, A. \& Hammiche, V. 1993. Pharmacopée traditionnelle saharienne: Sahara septentrional. In: Schröder, E., Balansard, G., Cabalion, P., Fleurentin, J. \& Mazars, G. (Eds.). Médicaments et aliments: approche ethnopharmacologique. Pp. 169-171. 2nd Eur. Sym. Ethnopharm. 11th Conf. Int. Ethnomed., Heidelberg.

N.I.S.P. (National Institute of Public Health) 1997. Evaluation de programme national de lutte contre l'envenimation scorpionique. Dép. Inf. San. Unit. Santé Environ.

N.I.S.P. (National Institute of Public Health) 2010. Envenimation scorpionique. Rapport annuel sur la situation épidémiologique en Algérie, Dép. Inf. San. Unit. Santé Environ. 62 pp.

Reynier, C. 1954. Tiout (Sud oranais), étude historique, géographique et médicale. Arch. Inst. Pasteur 32(2): 107-139. 
Sadine, S.E. 2005. Contribution à l'étude bioécologique de quelques espèces du scorpion; Androctonus australis, Androctonus amoreuxi, Buthacus arenicola, Buthus tunetanus et Orthochirus innesi dans la wilaya de Ouargla, Mém. Ing. Et. Biol. Ecol. Environ., Univ. Ouargla, Algérie. 100 pp.

Soulaymani, R., Semlali, I., Skalli, S. \& Tebaa, A. 1999. Épidémiologie des piqûres de scorpions au Maroc. Esp. Méd. 6: 288-290.

Tabuti, J.R.S., Lye, K.A. \& Dhillion, S.S. 2003. Traditional herbal drugs of Bulamogi, Uganda: plants, use and administration. J. Ethnopharm. 88: 19-44.

Vachon, M. 1952. Etude sur les scorpions. Inst. Pasteur d'Algérie, Alger. 479 pp. 